MATHEdunesa

Jurnal Ilmiah Pendidikan Matematika Volume 10 No.1 Tahun 2021

ISSN :2301-9085

\title{
PENGEMBANGAN E-COMIC MATEMATIKA BERBASIS PENDIDIKAN MATEMATIKA REALISTIK (PMR) BERMUATAN ETNOMATEMATIKA MATERI ARITMETIKA SOSIAL
}

\author{
Aldio Rahmata \\ Pendidikan Matematika, FMIPA, Universitas Negeri Surabaya, email: aldio.17030174052@mhs.unesa.ac.id \\ Rooselyna Ekawati \\ Pendidikan Matematika, FMIPA, Universitas Negeri Surabaya, email: rooselynaekawati@unesa.ac.id
}

\begin{abstract}
Abstrak
Pada era generasi Z, dunia pendidikan perlu memanfaatkan teknologi dalam mengembangkan bahan ajar yang menarik dan dapat meningkatkan motivasi siswa. Namun pada kenyataannya masih banyak pendidik yang menggunakan cara konvensional dalam menyampaikan materi pelajaran, sehingga siswa kurang berminat untuk belajar matematika yang sifatnya abstrak. Penelitian ini bertujuan untuk mengembangkan media pembelajaran e-comic matematika berbasis pendidikan matematika realistik (PMR) bermuatan etnomatematika materi aritmetika sosial yang layak digunakan dalam pembelajaran dengan memenuhi kriteria valid, praktis, dan efektif. Pendekatan yang digunakan pada penelitian ini adalah deskriptif dan analisis data secara kuantitatif. Langkah penelitian pengembangan e-comic matematika diadaptasi dari model ADDIE (Analyze, Design, Develop, Implement, dan Evaluate). Hasil penelitian menunjukkan bahwa $e$-comic matematika berbasis pendidikan matematika realistik (PMR) bermuatan etnomatematika materi aritmetika sosial telah mencapai kevalidan $82,95 \%$ dengan kategori valid. Kevalidan diperoleh dari hasil penilaian oleh dua validator ahli media dan ahli materi. Kepraktisan e-comic matematika mencapai persentase $84,18 \%$ dengan kategori praktis. Kepraktisan diukur dari hasil penilaian angket uji kepraktisan yang dilakukan oleh 12 siswa selaku subjek penelitian. Sedangkan keefektifan e-comic mencapai $83,33 \%$ dengan kategori sangat efektif. Keefektifan diukur berdasarkan banyaknya siswa yang mencapai KKM setelah menggunakan e-comic matematika. Sehingga dapat disimpulkan bahwa $e$-comic matematika berbasis pendidikan matematika realistik (PMR) bermuatan etnomatematika pada materi aritmetika sosial layak digunakan dalam pembelajaran dan diharapkan dapat menjadi referensi sumber belajar oleh pendidik untuk dapat menarik minat serta meningkatkan hasil belajar siswa dalam materi aritmetika sosial.
\end{abstract}

Kata Kunci: e-comic, pendidikan matematika realistik (PMR), etnomatematika, aritmetika sosial.

\begin{abstract}
In the era of generation $\mathrm{Z}$, the world of education needs to take advantage of technology for developing interesting teaching materials and increase student motivation. But in fact there are still many educators who use conventional methods of teaching, so that students are less interested in learning mathematics. This study aims to develop an e-comic mathematics learning media based on realistic mathematics education (RME) containing ethnomathematics social arithmetic material that is suitable for use in learning with valid, practical, and effective criteria. The approach used in this research is descriptive and quantitative data analysis. The research steps for e-comic mathematics development were adapted from the ADDIE model (Analyze, Design, Develop, Implement, and Evaluate). The results showed that the e-comic mathematics based on realistic mathematics education (RME) containing ethnomathematics with social arithmetic material has reached $82.95 \%$ validity in the valid category. Validity is obtained from the results of the assessment by two media expert and material experts. The practicality of e-comic mathematics reached a percentage of $84.18 \%$ in the practical category. Practicality is measured from the results of the practicality test questionnaire conducted by 12 students as research subjects. Meanwhile, the effectiveness of e-comics reached $83.33 \%$ in the very effective category. The effectiveness is measured based on the number of students who reach the KKM after using e-comic mathematics. So it can be concluded that the e-comic mathematics based on realistic mathematics education (RME) contains ethnomathematics in social arithmetic material are suitable for use in learning and are expected to be a reference source of learning by educators to attract interest and improve student learning outcomes in social arithmetic material.
\end{abstract}

Keywords: e-comics, realistic mathematics education (RME), ethnomathematics, social arithmetic. 


\section{PENDAHULUAN}

Pada era generasi $\mathrm{Z}$ seperti saat ini, teknologi informasi dan komunikasi telah banyak terlibat dalam berbagai aspek, termasuk dalam dunia pendidikan yang mulai menerapkan pembelajaran berbasis komputer. Menurut Mashuri (2019), pembelajaran berbasis komputer merupakan hasil inovasi pembelajaran dengan memanfaatkan teknologi yang telah berkembang saat ini. Pembelajaran berbasis komputer tidak lagi menggunakan bahan ajar konvensional, namun telah memanfaatkan komputer untuk membuat bahan ajar yang baru, sehingga proses belajar mengajar menjadi lebih menarik dan menantang bagi guru maupun siswa (Mashuri, 2019). Basis komputer ini juga disebut dengan elektronik. Namun tidak sebatas komputer, media pembelajaran juga dapat diakses melalui smartphone bersistem operasi android, sehingga dapat langsung didistribusikan dan diakses oleh siswa secara langsung maupun tidak langsung.

Hasil studi Programme for International Student Assessment (PISA) 2018 telah dirilis pada hari Selasa, 3 Desember 2019. Berdasarkan hasil analisa Tohir (2019), peringkat PISA Indonesia tahun 2018 turun apabila dibandingkan dengan hasil PISA tahun 2015. Untuk kategori matematika, Indonesia berada di peringkat 7 dari bawah (73) dengan skor rata-rata 379 (Tohir, 2019). Berdasarkan hasil Ujian Nasional tahun 2019 pada website resmi Kemdikbud (2019) diperoleh capaian rata-rata nilai mata pelajaran Matematika adalah 45,56 (SMP), 42,24 (MTs). Nilai rata-rata Matematika masih menjadi yang terendah diantara mata pelajaran lain. Dari data tersebut dapat disimpulkan bahwa kemampuan siswa dalam matematika sangat rendah. Rendahnya kualitas hasil belajar matematika diakibatkan oleh aktivitas pembelajaran yang dilakukan di kelas masih sebatas pengetahuan yang belum meresap kepada kemampuan untuk mengaplikasikan dan mengaitkan pembelajaran matematika pada kehidupan sehari-hari, sehingga kemampuan pemecahan masalah matematika siswa rendah (Irawan\&Kencanawaty, 2017). Untuk menanggulangi masalah tersebut, solusi alternatif yang mungkin dapat digunakan adalah menggunakan media pembelajaran.

Menurut Zainiyati (2017:63), media pembelajaran adalah sarana untuk menyalurkan pesan dari pengirim ke penerima dengan tujuan merangsang pikiran, perasaan, perhatian, dan minat serta kemauan siswa sedemikian rupa sehingga proses belajar terjadi dalam rangka mencapai tujuan pembelajaran yang efektif. Salah satu media pembelajaran yang dapat digunakan dalam pembelajaran adalah komik. Menurut Siregar, dkk. (2018), komik merupakan karya seni berupa kumpulan panel berisi gambar dengan susunan sedemikian rupa membentuk alur cerita, dengan dialog antar tokoh dimuat dengan balon kata. Berdasarkan hasil penelitian dari Nida, dkk. (2017), diperoleh rata-rata hasil belajar kelas menggunakan comic math lebih baik dibandingkan rata-rata hasil belajar kelas konvensional.

Komik yang dibuat melalui media elektronik seperti komputer disebut e-comic, webcomic, atau mobile comic (Gumelar, 2011). E-comic telah mentransformasi komik cetak menjadi elektronik. Berdasarkan karakeristik komik yang dijelaskan oleh Gumelar (2011), maka penggunaan e-comic diharapkan dapat mem-backup konsep abstrak matematika yang diusung dengan ilustrasi atau simbol, sehingga dapat menarik perhatian siswa. Hal tersebut dikarenakan $e$-comic dapat memuat cerita yang bertujuan untuk mengajak siswa belajar matematika melalui peristiwa dalam e-comic, baik peristiwa yang pernah dialami maupun yang dapat dibayangkan oleh siswa. Menurut Siregar, dkk. (2019), e-comic dapat dipilih sebagai media pembelajaran matematika dikarenakan siswa gemar membaca komik atau buku-buku bergambar yang mampu menimbulkan imajinasi dan kemampuan berpikir siswa. Selain itu pada penelitian Hermawan, dkk. (2018), hasil wawancara antara peneliti dengan siswa, siswa menyatakan merasa senang dan tidak bosan dengan media pembelajaran $e$-comic dan mereka dapat memahami materi yang disampaikan. E-comic dibuat oleh seseorang berdasarkan faktor internal yang ditentukan oleh diri sendiri yaitu meliputi ide, tema cerita, plot, panel, karakter-karakter, serta adat\&budaya (Gumelar, 2011). Selain itu juga terdapat faktor eksternal yang dapat mempengaruhi faktor internal. Untuk itu, cerita di dalam e-comic matematika dapat berupa aktivitas kegiatan manusia dalam kehidupan sehari-hari yang dihubungkan dengan konsep matematika.

Dalam pendidikan matematika, integrasi antara konsep matematika dengan kehidupan nyata (realistis) dikaji dalam pendidikan matematika realistik (PMR) (Lestari\&Ekawati, 2019). Karakteristik pendidikan matematika realistik (PMR) yang berfokus pada aktivitas manusia sebagai jembatan untuk mengonstruksi konsep matematika, sesuai dengan sifat komik yang dapat memuat cerita dengan maksud dan tujuan yang dapat disesuaikan dengan keinginan creator komik. Salah satu aktivitas nyata dalam masyarakat adalah berupa kebiasaan, kearifan, atau kebudayaan yang terbentuk dalam lingkungan masyarakat setempat. Membangun lingkungan belajar dan menciptakan pengalaman belajar dapat dilakukan dengan memasukkan budaya sebagai bagian dari proses pembelajaran (Nur, 2018).

Menurut Hardiarti (2017), suatu kajian tentang memahami matematika dari sebuah budaya disebut 
etnomatematika. Istilah "etno" menggambarkan semua hal yang membentuk identitas suatu kelompok, yaitu bahasa, kode, nilai-nilai, jargon, keyakinan, makanan dan pakaian, kebiasaan, dan sifat-sifat fisik. Sedangkan matematika mencakup pandangan yang luas mengenai aritmetika, mengklasifikasikan, mengurutkan, menyimpulkan, dan memodelkan.

Salah satu etnomatematika yang ada di Kabupaten Sidoarjo adalah satuan lokal yang telah dieksplorasi oleh Rachmawati (2011). Ia mengatakan bahwa dalam aktivitas jual beli menggunakan satuan lokal terdapat konsep matematika yang meliputi mengelompokkan, menghitung, serta menakar. Menurut Rachmawati (2011) terdapat beberapa satuan lokal, yaitu:

"Satuan lokal bahan makanan, meliputi satuan sajumput dan sacakup untuk satuan cabai, unting untuk satuan ikat kangkung, sawi, maupun kacang panjang, dompol/ombyok untuk satuan tunggal petai, tundun serta cengkeh untuk satuan tunggal pisang, serta sejinah untuk satuan setiap 10 biji jagung, ataupun kue dan makananmakanan tertentu".

Pada Permendikbud Republik Indonesia No. 37 tahun 2018 tertera kompetensi inti (keterampilan) yang berbunyi "Menyelesaikan masalah berkaitan dengan aritmetika sosial (penjualan, pembelian, potongan, keuntungan, kerugian, bunga tunggal, persentase, bruto, neto, tara)". Aritmetika sosial merupakan salah satu bab mata pelajaran matematika kelas VII semester 2 yang banyak berguna dalam menyelesaikan permasalahan di kehidupan sehari-hari. Namun dari hasil Ujian Nasional SMP sederajat tahun 2019 diperoleh persentase siswa yang menjawab benar soal tentang aritmetika sosial adalah 41,29\% (Kemdikbud, 2019).

Berdasarkan uraian di atas mengenai media pembelajaran e-comic, masalah kualitas belajar yang disebabkan oleh persepsi siswa terhadap matematika, keberadaan konsep matematika dalam konteks kebudayaan masyarakat, serta rendahnya kemampuan siswa pada materi aritmetika sosial yang banyak bermanfaat dalam kehidupan sehari-hari, maka perlu adanya pengembangan media pembelajaran e-comic matematika pada materi aritmetika sosial dengan pendidikan matematika realistik (PMR) bermuatan etnomatematika satuan lokal masyarakat Sidoarjo.

Pada penelitian Siregar, dkk (2019) yang berjudul "Pengembangan Media Pembelajaran E-comic dalam Pembelajaran Matematika", persamaan penelitian tersebut dengan penelitian ini adalah materi yang diusung yaitu aritmetika sosial. Namun pada penelitian tersebut $e$-comic belum memegang basis apapun, sedangkan pada penelitian ini $e$-comic telah mengusung basis pendidikan matematika realistik (PMR) yang memuat etnomatematika, sehingga $e$-comic dapat tersaji dengan jaminan karakteristik dan prinsip yang sesuai untuk digunakan sebagai bahan ajar matematika. Selain itu terdapat penelitian oleh Lestari (2020) yang berjudul "Pengembangan E-comic Matematika Berbasis Pendekatan Matematika Realistik pada Materi Perbandingan Senilai" yang memiliki kesamaan basis dengan penelitian ini yaitu menggunakan pendekatan matematika realistik. Namun pada penelitian ini, basis pendidikan matematika realistik (PMR) diintegrasikan dengan etnomatematika. Selain itu terdapat perbedaan materi. Pada penelitian tersebut mengusung materi perbandingan senilai, namun pada penelitian ini adalah materi aritmetika sosial.

Penelitian ini bertujuan untuk memperoleh suatu media pembelajaran e-comic matematika berbasis PMR bermuatan etnomatematika pada materi aritmetika sosial yang layak untuk digunakan sebagai bahan ajar dengan memenuhi kriteria valid, praktis, serta efektif. Sehingga pelaksanaan pembelajaran di kelas dan peningkatan kemampuan siswa terutama pada materi aritmetika sosial menjadi lebih baik. Selain itu penelitian ini dapat dikembangkan oleh peneliti berikutnya dalam topik yang serupa untuk menciptakan media pembelajaran dengan kualitas yang lebih baik.

\section{METODE}

Pada penelitian ini yang digunakan adalah penelitian pengembangan. Model pengembangan yang digunakan mengacu pada paradigma pengembangan ADDIE (Analyze, Design, Develop, Implement, Evaluate). Tahapan pengembangan pada penelitian ini dijelaskan pada diagram di bawah ini.

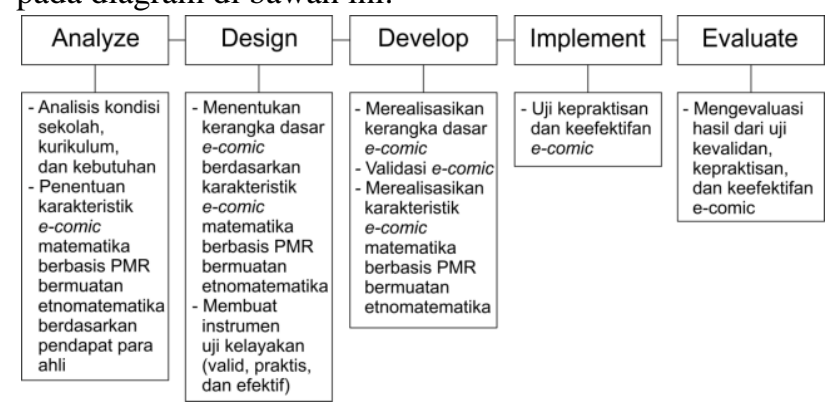

Gambar 1. Alur Penelitian Pengembangan E-comic Matematika Berbasis PMR Bermuatan Etnomatematika

Suatu produk penelitian pengembangan akan layak untuk digunakan apabila diketahui kualitas produknya (Siswono, 2019). Dalam penelitian ini, kriteria kualitas produk ditentukan sebagai berikut :

\section{Valid}

Kevalidan dari media e-comic matematika berbasis Pendidikan Matematika Realistik (PMR) bermuatan etnomatematika diperoleh berdasarkan hasil uji validitas yang dilakukan oleh ahli media berbasis pendidikan 
matematika realistik (PMR) dan etnomatematika, sekaligus ahli materi dengan penilaian dan saran terkait aspek kevalidan e-comic matematika berbasis PMR bermuatan etnomatematika pada materi aritmetika sosial. Media e-comic matematika dinyatakan valid apabila minimal memenuhi kriteria valid yang diadaptasi dari Akbar (2017:40).

Tabel 1. Kriteria Uji Validitas

\begin{tabular}{|c|l|}
\hline Nilai Validitas & \multicolumn{1}{c|}{ Tingkat Validitas } \\
\hline $85 \%<V \leq 100 \%$ & $\begin{array}{l}\text { Sangat Valid, atau dapat digunakan tanpa } \\
\text { revisi }\end{array}$ \\
\hline $70 \%<V \leq 85 \%$ & $\begin{array}{l}\text { Valid, atau dapat digunakan namun perlu } \\
\text { direvisi kecil }\end{array}$ \\
\hline $50 \%<V \leq 70 \%$ & $\begin{array}{l}\text { Kurang Valid, disarankan tidak } \\
\text { dipergunakan karena perlu revisi besar }\end{array}$ \\
\hline $0 \% \leq V \leq 50 \%$ & Tidak Valid, atau tidak boleh dipergunakan \\
\hline
\end{tabular}

Rumus menentukan nilai (\%) kriteria kevalidan adalah :

$$
\text { Validitas }=\frac{T S e}{T S h} \times 100 \% \ldots(1)
$$

Dengan keterangan :

TSe $($ Total Skor Empirik $)=$ total nilai hasil angket validasi.

TSh $($ Total Skor Maksimal $)=$ total nilai maksimal angket validasi.

\section{Praktis}

Kepraktisan media e-comic matematika berbasis PMR bermuatan etnomatematika yang dikembangkan didasarkan pada hasil penilaian angket respon. E-comic matematika dikatakan praktis apabila nilai dari angket respon minimal memenuhi kriteria praktis yang diadaptasi dari Akbar (2017:40).

Tabel 2. Kriteria Uji Kepraktisan

\begin{tabular}{|c|l|}
\hline Nilai Kepraktisan & \multicolumn{1}{|c|}{ Tingkat Kepraktisan } \\
\hline $85 \%<P \leq 100 \%$ & $\begin{array}{l}\text { Sangat Praktis, atau dapat digunakan tanpa } \\
\text { revisi }\end{array}$ \\
\hline $70 \%<P \leq 85 \%$ & $\begin{array}{l}\text { Praktis, atau dapat digunakan namun perlu } \\
\text { direvisi kecil }\end{array}$ \\
\hline $50 \%<P \leq 70 \%$ & $\begin{array}{l}\text { Kurang Praktis, disarankan tidak dipergunakan } \\
\text { karena perlu revisi besar }\end{array}$ \\
\hline $0 \% \leq P \leq 50 \%$ & Tidak Praktis, atau tidak boleh dipergunakan \\
\hline
\end{tabular}

Rumus menentukan nilai (\%) kriteria kepraktisan adalah :

$$
\text { Kepraktisan }=\frac{S R e}{S R h} \times 100 \% \ldots(2)
$$

Dengan keterangan :

SRe $($ Skor Rata-rata Empirik $)=$ nilai rata-rata hasil angket kepraktisan.

SRh $($ Total Skor Rata-rata Maksimal $)=$ nilai rata-rata maksimal angket kepraktisan.

\section{Efektif}

Dalam penelitian ini, media e-comic matematika berbasis PMR bermuatan etnomatematika dikatakan efektif apabila $>60 \%$ siswa telah memenuhi KKM, seperti pada kriteria keefektifan Akbar (2017:42).

Tabel 3. Kriteria Uji Keefektifan

\begin{tabular}{|c|l}
\hline Nilai Validitas & \multicolumn{1}{c}{ Tingkat Keefektifan } \\
\hline $80 \%<E \leq 100 \%$ & $\begin{array}{l}\text { Sangat Efektif, atau dapat digunakan tanpa } \\
\text { revisi }\end{array}$ \\
\hline $60 \%<E \leq 80 \%$ & $\begin{array}{l}\text { Efektif, atau dapat digunakan namun perlu } \\
\text { direvisi kecil }\end{array}$ \\
\hline $40 \%<E \leq 60 \%$ & $\begin{array}{l}\text { Kurang Efektif, disarankan tidak dipergunakan } \\
\text { karena perlu revisi besar }\end{array}$ \\
\hline $20 \%<E \leq 40 \%$ & Tidak Efektif, atau tidak boleh dipergunakan \\
\hline $0 \% \leq E \leq 20 \%$ & $\begin{array}{l}\text { Sangat Tidak Efektif, atau tidak boleh } \\
\text { dipergunakan }\end{array}$ \\
\hline
\end{tabular}

Perhitungan untuk persentase keefektifan adalah :

$$
\begin{aligned}
\text { Efektifitas }= & \frac{\sum \text { subjek mencapai KKM }}{\sum \text { subjek }} \\
& \times 100 \% \ldots(3)
\end{aligned}
$$

\section{HASIL DAN PEMBAHASAN}

\section{Hasil Penelitian}

Hasil dari penelitian pengembangan ini merupakan adaptasi dari langkah-langkah penelitian pengembangan model ADDIE yang merupakan singkatan dari Analyze, Design, Develop, Implement, and Evaluate. Untuk itu peneliti menjabarkan hasil penelitian sebagai berikut:

\section{Tahap Analyze}

Pada tahap ini peneliti melakukan beberapa analisis seperti analisis kondisi, kurikulum, dan kebutuhan yang pada akhirnya digunakan peneliti untuk membuat landasan konsep pengembangan media yang akan dibuat. Hasil dari wawancara peneliti dengan salah satu guru matematika SMP Negeri 1 Krembung memberikan informasi bahwa sekolah sedang melaksanakan pembelajaran daring akibat pandemi covid-19, dimana pembelajaran daring cenderung memiliki banyak kelemahan. Berdasarkan hasil wawancara peneliti dengan salah satu siswa, diperoleh informasi bahwa siswa kesulitan dalam memahami pelajaran matematika yang disampaikan hanya menggunakan buku elektronik dari sekolah. Penjelasan guru yang cenderung konvensional membuat siswa tidak termotivasi dan semakin mengalami kesulitan dalam memahami materi.

Peneliti melanjutkan dengan analisis kurikulum. Kurikulum yang digunakan SMP Negeri 1 Krembung adalah kurikulum 2013. Materi aritmetika sosial belum diajarkan pada siswa kelas VII. Sedangkan KKM yang ditentukan untuk siswa kelas VII adalah 75.

Pada saat melakukan analisis kebutuhan, peneliti menangkap adanya urgensi dalam hal meningkatkan motivasi belajar siswa dalam pembelajaran daring. Untuk itu peneliti akan menggunakan media $e$-comic matematika sebagai salah satu alternatif bahan ajar yang dapat diakses melalui smartphone dengan ekstensi .apk sehingga lebih mudah diakses dan di- 
instal di masing-masing smartphone milik siswa maupun guru.

Peneliti pada akhirnya melakukan analisis teoritik mengenai media yang akan dibuat, dengan mengaitkan hasil penelitian Cahdriyana\&Ricardo (2016) mengenai prinsip media pembelajaran berbasis komputer untuk siswa SMP; prinsip komik yang diadaptasi dari buku karangan Gumelar (2011); prinsip dan karakteristik pendidikan matematika realistik (PMR) oleh Freudhental (1991); dan definisi etnomatematika oleh D’Ambrasio (1994:449) dalam Hardiarti (2017). Dari sumber-sumber tersebut peneliti menentukan karakteristik e-comic matematika berbasis pendidikan matematika realistik (PMR) bermuatan etnomatematika sesuai pada tabel berikut.

Tabel 4. Karakteristik E-Comic Matematika Berbasis PMR Bermuatan Etnomatematika

\begin{tabular}{|l|l|c|}
\hline No. & \multicolumn{1}{|c|}{ Karakteristik } & Kode \\
\hline 1. & Menarik Bagi Siswa & $K 1$ \\
\hline 2. & Sesuai dengan karakteristik Siswa & $K 2$ \\
\hline 3. & $\begin{array}{l}\text { Dikembangkan menggunakan teknologi } \\
\text { komputer }\end{array}$ & $K 3$ \\
\hline 4. & Memuat konteks etnomatematika & $K 4$ \\
\hline 5. & Memuat prinsip dan karakteristik PMR & $K 5$ \\
\hline
\end{tabular}

\section{Tahap Design}

Pada tahap desain, peneliti menyusun e-comic matematika mulai dari dasar-dasar yang diperoleh dari tahap analisis. Pada tahap ini peneliti menentukan alur cerita yang akan mengusung konsep aritmetika sosial yang disampaikan secara bertahap dengan mengacu pada prinsip dan karakteristik pendidikan matematika realistik (PMR). Untuk memenuhi prinsip dan karakteristik PMR, peneliti mengurutkan panel berdasarkan tahapan pemerolehan konsep aritmetika sosial secara non formal berupa jembatan/model. Peneliti juga menggunakan pengetahuan awal siswa mengenai materi sebelum aritmetika sosial seperti perbandingan atau operasi dasar matematika yang telah diintegrasikan ke dalam cerita dengan harapan siswa dapat secara mandiri mengonstruksi konsep aritmetika sosial. Selain itu di dalam e-comic perlu terdapat bagian dimana siswa terlibat aktif dalam pemecahan masalah, sehingga peneliti membuat halaman interaktif pada beberapa panel e-comic.

Pada akhirnya peneliti menentukan cerita $e$-comic akan berisi tentang kegiatan lomba bazar makanan di sebuah sekolah menengah pertama. Tokoh utama pada e-comic ada 3 dari total tokoh yang dimunculkan pada komik yaitu 6 tokoh. Beberapa jenis halaman dalam cerita e-comic matematika berbasis PMR bermuatan etnomatematika materi aritmetika sosial adalah: (1) Halaman awal yang terdiri dari judul e-comic, tombol memulai dan tombol menuju halaman kompetensi dasar; (2) Halaman kompetensi dasar untuk mengetahui apa yang akan dipelajari dalam e-comic matematika; (3) Halaman petunjuk untuk mengetahui cara membaca e-comic matematika; (4) Halaman perkenalan untuk mengenalkan tokoh utama dalam $e$ comic matematika; (5) Halaman cerita awal yang dimulai dari dua tokoh utama yang membahas mengenai lomba bazar di sekolah; (6) Halaman etnomatematika yang merupakan bagian dari cerita yang berisi pengenalan etnomatematika satuan lokal masyarakat Sidoarjo dalam jual beli; dan (7) Halaman interaktif yang berisi tentang pertanyaan yang harus dijawab oleh siswa, serta respon benar atau salah dari jawaban yang dipilih sekaligus pembahasan beberapa pertanyaan terkait dengan untung, rugi, potongan harga, dan persentase keuntungan.

Dalam penelitian pengembangan, suatu media dikatakan layak digunakan dalam pembelajaran apabila memenuhi kriteria valid, praktis, dan efektif. Maka pada akhir tahap desain, peneliti membuat instrumen yang berisi poin-poin penting untuk menjadi acuan dalam pembuatan e-comic matematika. Instrumen validasi dan kepraktisan berbentuk kusioner untuk diujikan pada validator dan siswa. Sedangkan instrumen keefektifan berupa soal untuk menguji pemahaman siswa setelah belajar dengan $e$-comic.

\section{Tahap Develop}

Pada tahap pengembangan, peneliti mulai membuat desain secara keseluruhan dan mendetail mulai dari tokoh, balon kata, teks, tombol, background, dll. menggunakan aplikasi Corel Draw. Resolusi panel $e$ comic yang digunakan adalah $1.280 \times 720$ pixel, atau rasio 16:9 landscape dengan kualitas $720 \mathrm{p}$. Jenis font yang digunakan dalam percakapan e-comic matematika adalah Comic Sans MS. Pemilihan ukuran teks telah disesuaikan dengan ukuran layar smartphone yang cenderung lebih kecil dibandingkan laptop atau komputer. Sehingga dapat tetap terbaca ketika dicoba pada smartphone. Peneliti melakukan beberapa proses sebagai berikut:

\section{a. Merealisasikan Kerangka Dasar}

Peneliti mengembangkan desain sesuai dengan kerangka dasar pada tahap sebelumnya. Penelti menjabarkannya sebagai berikut: (1) Pada halaman awal e-comic matematika terdapat judul, tombol $\mathrm{KD}$, tombol mulai, dan background yang menggambarkan inti cerita e-comic matematika. Background dibuat semenarik mungkin dengan memunculkan 2 dari 3 tokoh utama agar menarik perhatian siswa pada kesan pertamanya setelah 


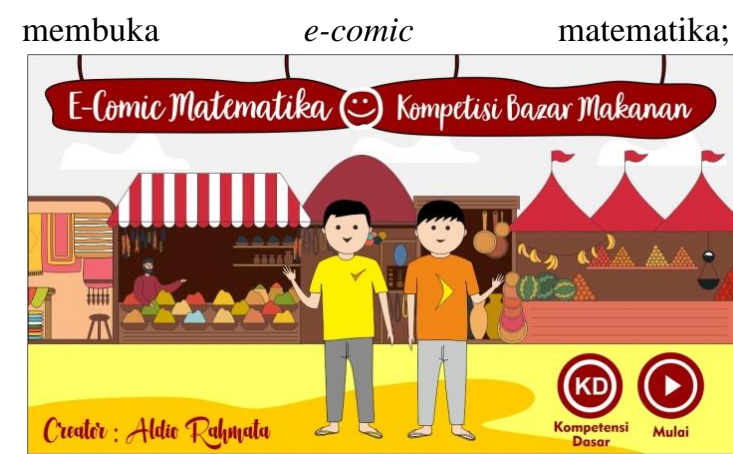

Gambar 2. Halaman Awal E-comic

(2) Selanjutnya adalah halaman kompetensi dasar yang memunculkan indikator pencapaian kompetensi (IPK). Halaman tersebut memperjelas bahwa e-comic matematika berbasis PMR bermuatan etnomatematika materi aritmetika sosial berfokus pada sub materi penjualan, pembelian, potongan harga, keuntungan, kerugian, dan persentase; (3) Halaman petunjuk, menjelaskan mengenai cara membaca balon kata pada e-comic matematika yaitu dari kiri ke kanan atau atas ke bawah. Selain itu pada halaman petunjuk mulai terdapat tombol panah menghadap ke kiri atau kanan yang masing-masing merupakan tombol untuk kembali ke halaman sebelumnya atau tombol untuk menuju ke halaman berikutnya; (4) Pada halaman pengenalan tokoh, ditunjukkan bahwa tokoh utama pada $e$-comic matematika merupakan siswa kelas VII SMP. Tokoh bernama Komet dan Kosim merupakan yang paling sering muncul dalam e-comic matematika. Pemilihan tokoh dan latar tempat disesuaikan dengan sasaran pembaca e-comic yang juga merupakan siswa kelas VII SMP di Kabupaten Sidoarjo; (5) Pada bagian awal cerita, e-comic menampilkan adanya aktvitas utama yang akan dilakukan oleh tokoh, yaitu dua tokoh akan melakukan belanja dalam rangka mempersiapkan

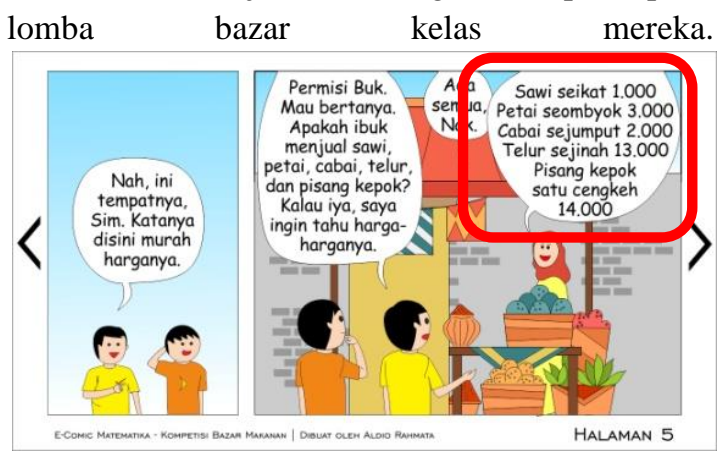

Gambar 3. Salah Satu Halaman Etnomatematika

Gambar di atas merupakan salah satu halaman yang memuat etnomatematika. Halaman tersebut mulai menunjukkan adanya etnomatematika satuan lokal masyarakat Sidoarjo saat melakukan jual beli. Satuan lokal yang terdapat dalam e-comic adalah satuan ikat, ombyok, secakup, sejinah, dan cengkeh.

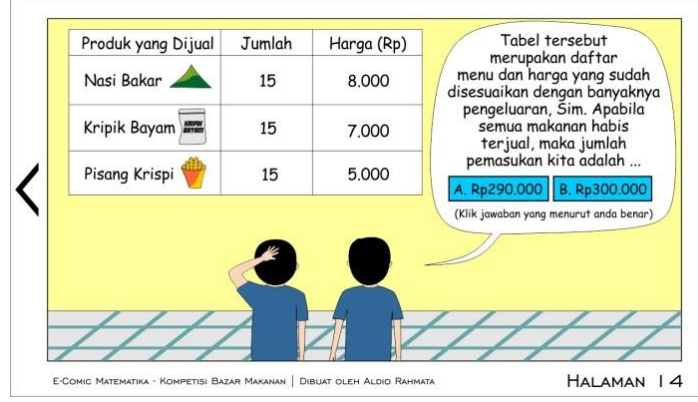

Gambar 4. Salah Satu Halaman Permasalahan

Pada halaman interaktif, siswa diajak untuk ikut dalam menjawab soal dalam rangka menuju ke konsep sub materi aritmetika sosial. Pada halaman ini siswa tidak bisa melanjutkan ke halaman berikutnya apabila belum menjawab soal dengan menekan tombol pilihan jawaban yang berwarna biru muda. Ketika salah satu jawaban ditekan, maka tampilan beralih ke halaman respon. Pada halaman respon, terdapat keterangan jawaban benar atau jawaban belum benar, dan di bawah keterangan terdapat pembahasan.

b. Validasi E-comic Matematika

Validasi dilakukan oleh ahli media dan ahli materi. Terdapat 2 validator yang merupakan ahli media pembelajaran sekaligus ahli materi Pendidikan Matematika Realistik (PMR) serta etnomatematika. Validasi dilakukan untuk menguji tingkat kevalidan $e$-comic matematika berdasarkan aspek penilaian pada instrumen validitas $e$-comic matematika berbasis PMR bermuatan etnomatematika materi aritmetika sosial.

Tabel 5. Hasil Validasi Dua Validator

\begin{tabular}{|c|c|c|c|}
\hline No. & Aspek yang Dinilai & $V_{1}$ & $V_{2}$ \\
\hline \multirow[t]{13}{*}{1.} & Aspek Media & & \\
\hline & $\begin{array}{l}\text { Kejelasan petunjuk penggunaan } e \text { - } \\
\text { comic matematika }\end{array}$ & 3 & 3 \\
\hline & Kemudahan memahami alur cerita & 4 & 3 \\
\hline & Kesesuaian gambar dengan tulisan & 4 & 3 \\
\hline & $\begin{array}{l}\text { Kejelasan bahasa dan pilihan kata } \\
\text { yang digunakan }\end{array}$ & 3 & 3 \\
\hline & $\begin{array}{l}\text { Bahasa yang sesuai dengan } \\
\text { perkembangan kognitif siswa }\end{array}$ & 3 & 3 \\
\hline & $\begin{array}{l}\text { Keruntutan penyajian } e \text {-comic } \\
\text { matematika }\end{array}$ & 3 & 3 \\
\hline & $\begin{array}{l}\text { Tidak memuat kata-kata kasar, } \\
\text { mengandung SARA }\end{array}$ & 3 & 4 \\
\hline & Ketepatan istilah & 3 & 4 \\
\hline & Keseuaian keterangan gambar & 4 & 4 \\
\hline & Kualitas gambar dan warna stabil & 4 & 4 \\
\hline & $\begin{array}{l}\text { Pemilihan karakter sesuai dengan } \\
\text { karakteristik siswa }\end{array}$ & 4 & 3 \\
\hline & $\begin{array}{l}\text { Kemenarikan penyajian } \text { e-comic } \\
\text { matematika }\end{array}$ & 4 & 3 \\
\hline
\end{tabular}




\begin{tabular}{|c|l|c|c|}
\hline \multirow{2}{*}{2.} & $\begin{array}{l}\text { Panel pilihan jawaban } \\
\text { mengakibatkan siswa berpartisipasi }\end{array}$ & 3 & 3 \\
\cline { 2 - 4 } & $\begin{array}{l}\text { Aspek Materi } \\
\text { Kesesuaian isi } \text {-comic matematika } \\
\text { dengan KD dan IPK }\end{array}$ & 4 & 4 \\
\cline { 2 - 4 } & Kejelasan konsep aritmetika sosial & 3 & 3 \\
\cline { 2 - 4 } & $\begin{array}{l}\text { Kebenaran konsep materi ditinjau } \\
\text { dari segi keilmuan }\end{array}$ & 3 & 4 \\
\cline { 2 - 4 } $\begin{array}{l}\text { Kejelasan gambar dan balon } \\
\text { percakapan dalam menyampaikan } \\
\text { materi aritmetika sosial }\end{array}$ & 3 & 4 \\
\cline { 2 - 4 } $\begin{array}{l}\text { Kemudahan uraian materi } \\
\text { aritmetika sosial dalam } e \text {-comic } \\
\text { matematika untuk dipahami }\end{array}$ & 3 & 3 \\
\cline { 2 - 4 } & $\begin{array}{l}\text { Keruntutan penyampaian materi } \\
\text { aritmetika sosial }\end{array}$ & 3 & 3 \\
\cline { 2 - 4 } $\begin{array}{l}\text { Kesesuaian tingkat kesulitan dan } \\
\text { keabstrakan konsep dengan } \\
\text { perkembangan kognitif siswa }\end{array}$ & 3 & 3 \\
\cline { 2 - 4 } $\begin{array}{l}\text { Kejelasan konteks etnomatematika } \\
\text { "penggunaan satuan lokal } \\
\text { masyarakat Sidoarjo" }\end{array}$ & 4 & 3 \\
\hline $\begin{array}{l}\text { Kesesuaian konsep dalam } e \text {-comic } \\
\text { matematika dengan prinsip } \\
\text { pendidikan matematika realistik } \\
\text { (PMR) }\end{array}$ & 3 & 2 \\
\hline
\end{tabular}

Hasil dari validasi oleh 2 validator diperoleh persentase validitas e-comic matematika berbasis PMR bermuatan etnomatematika materi aritmetika sosial adalah 82,95\%. Berdasarkan kriteria uji kevalidan yang diadaptasi dari Akbar (2017:42), maka e-comic matematika berbasis PMR bermuatan etnomatematika materi aritmetika sosial dinyatakan "valid dengan sedikit revisi". Seperti halnya pada penelitian Nida, dkk. (2017) yang menyatakan bahwa comic math layak digunakan atau mendapat kategori sangat baik dengan sedikit revisi berdasarkan komentar atau saran dari validator ahli media dan ahli materi. Berikut adalah beberapa revisi dan perbaikan berdasarkan komentar dan saran dari kedua validator :

- Penulisan halaman lebih baik ditulis, misal : 4 dari (total) halaman. Sehingga siswa tahu kapan bacaan $e$-comic berakhir.

- Petunjuk pengerjaan soal pada halaman interaktif belum ada, sehingga perlu ditambahkan.

- Menambahkan narasi atau prolog di awal cerita, sehingga siswa tidak kaget dengan awal ceritanya.

- Etnomatematika satuan lokal masyarakat Sidoarjo perlu diperdalam dan diberikan ilustrasi agar lebih jelas.

- Menambahkan ending cerita supaya tidak berakhir dengan perhitungan. Misalnya dengan pendidikan karakter atau pesan moral.

- Prinsip dan karakteristik Pendidikan Matematika Realistik (PMR) belum nampak.
Perlu menambahkan ilustrasi agar siswa melakukan matematisasi horizontal sebelum menuju konsep formal atau rumus. Peneliti menjabarkan hasil revisi bagian ini pada sub tahap berikutnya yaitu implementasi karakteristik e-comic matematika.

\section{c. Implementasi Karakteristik E-comic Matematika Berbasis PMR Bermuatan Etnomatematika}

Karakteristik yang diharapkan muncul pada $e$ comic matematika berbasis PMR bermuatan etnomatematika telah ditentukan peneliti pada tahap analisis, sub tahap analisis kebutuhan. Berikut adalah implementasi karakteristik pada $e$ comic matematika yang telah divalidasi dan direvisi:

i) Menarik Bagi Siswa $(K 1)$

Halaman awal e-comic matematika telah dibuat semenarik mungkin sehingga diharapkan kesan pertama siswa terhadap e-comic matematika adalah menarik. Selain itu pemilihan warna, kualitas gambar, dan karakter desain dipertahankan agar tetap pada komposisi yang sesuai. Berdasarkan hasil validasi oleh dua validator, kemenarikan gambar mendapatkan nilai 3 (baik) dan 4 (sangat baik); sedangkan untuk kestabilan kualitas gambar dan warna, kedua validator memberi nilai 4 (sangat baik). Sehingga e-comic matematika berbasis PMR bermuatan etnomatematika telah memiliki karakteristik "menarik bagi siswa".

ii) Sesuai dengan Karakteristik Siswa (K2)

Pemilihan tokoh, karakter tokoh, alur cerita, serta konflik telah dibuat berdasarkan segmentasi usia siswa sebagai subjek pembaca $e$-comic yang merupakan siswa SMP kelas VII. Sehingga tokoh utama dalam e-comic matematika merupakan siswa SMP kelas VII yang sedang bersaing dalam mengikuti lomba bazar makanan di sekolahnya untuk memperingati hari ulang tahun sekolah. Pada penilaian validasi oleh dua validator, aspek "pemilihan karakter sesuai dengan karakteristik siswa" mendapatkan nilai 3 (baik) dan 4 (sangat baik).

Selain itu, penggunaan kata maupun bahasa telah disesuaikan dengan tingkat kognitif siswa SMP, sehingga hasil penilaian validasi pada aspek "bahasa yang digunakan mudah dipahami dan sesuai dengan perkembangan kognitif siswa" mendapatkan nilai 3 (baik) dari kedua validator. 
Berdasarkan penjelasan tersebut, maka $e$ comic matematika berbasis PMR bermuatan etnomatematika yang dibuat telah memiliki karakteristik "sesuai dengan karakteristik siswa".

iii) Dikembangkan Menggunakan Teknologi Komputer (K3)

E-comic matematika didesain langsung menggunakan aplikasi komputer yaitu Corel Draw. Dengan bantuan beberapa tools, tampilan e-comic menjadi fleksibel untuk diubah sesuai keinginan peneliti. Selain itu, menggunakan lembar kerja pada Corel Draw lebih ramah lingkungan dibandingkan menggunakan media konvensional seperti kertas. Sehingga memenuhi prinsip komik yang menyatakan bahwa komik harus kuat, ringan, dan ramah lingkungan (Gumelar, 2011).

Tahap akhir dari pembuatan $e$-comic adalah menjadikan kumpulan gambar hasil desain Corel Draw menjadi sebuah aplikasi e-comic dengan ekstensi .apk dan .exe sehingga dapat dioperasikan menggunakan smartphone android dan komputer. Untuk mengubah gambar menjadi ekstensi tersebut, peneliti menggunakan aplikasi Adobe Flash Professional.

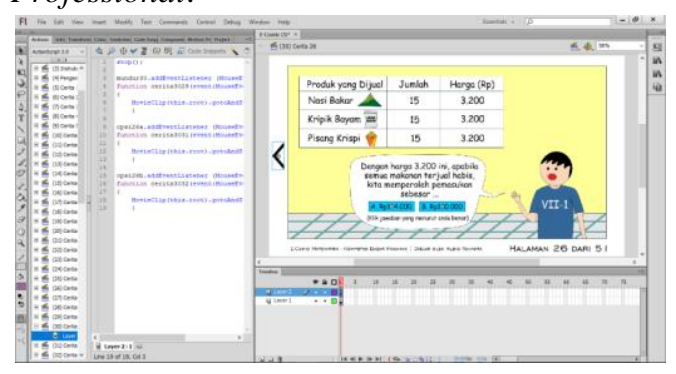

Gambar 5. Penggunaan Aplikasi Adobe Flash Professional

Dari penjelasan tersebut, maka e-comic matematika berbasis PMR bermuatan etnomatematika yang dibuat telah memiliki karakteristik "dikembangkan menggunakan teknologi komputer".

iv) Memuat Konteks Etnomatematika (K4)

E-comic matematika menyisipkan etnomatematika satuan lokal masyarakat Sidoarjo sebagai pendongkrak motivasi siswa dalam belajar matematika sekaligus menambah wawasan mereka. Selain itu validator telah memberikan saran agar konteks etnomatematika diperjelas dan diberikan ilustrasi agar siswa lebih memahami dan ingat mengenai etnomatematika tersebut. Dari penjelasan tersebut, e-comic matematika berbasis PMR bermuatan etnomatematika telah memiliki karakteristik "memuat konteks etnomatematika".

v) Memuat Prinsip dan Karakteristik PMR (K5)

Pada bagian ini peneliti telah melakukan revisi berdasarkan komentar validator ahli. Karena pada e-comic matematika yang dibuat sebelumnya hanya memunculkan prinsip "didactical phenomenology (fenomenologi didaktik) [K5pl]" yang merupakan penggunaan masalah dalam kehidupan sehari-hari. Sehingga peneliti melakukan perbaikan untuk memunculkan prinsip dan karakteristik PMR yang lainnya dalam e-comic.

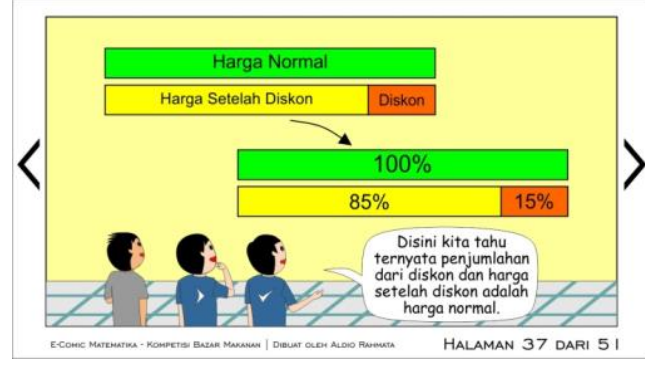

Gambar 6. Menambahkan Halaman untuk Memunculkan Prinsip PMR

Gambar tersebut telah memenuhi "guided reinvention (menemukan kembali) [K5p2]" yang merupakan salah satu prinsip PMR. Siswa sebagai pembaca $e$-comic matematika diajak untuk menemukan kembali konsep dasar dari diskon atau potongan harga melalui analogi sebuah diagaram batang, dimana penggunaan diagram pada gambar tersebut merupakan "penggunaan model [ $K 5 \mathrm{kl}]$ ]" yang merupakan salah satu karakteristik PMR sebagai jembatan untuk menuju konsep diskon dalam bentuk persentase di halaman berikutnya. Selain itu, dengan adanya contoh model tersebut, diharapkan siswa dapat mengembangkan modelnya sendiri ketika menyelesaikan masalah kontekstual. "Mengembangkan model [K5p3]" juga merupakan salah satu prinsip PMR.

Setelah mengunakan model, pembaca $e$ comic akan dibawa ke arah perhitungan menggunakan konsep lain yaitu perbandingan senilai yang telah dipelajari siswa sebelum materi aritmetika sosial. Konsep perbandingan akan mengarah pada rumus menentukan persentase. Dalam hal ini adalah persentase diskon. 


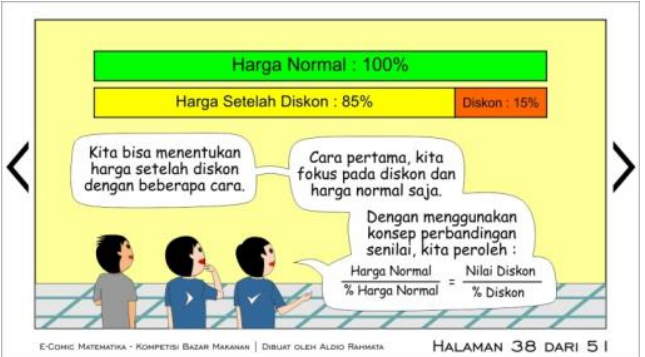

Gambar 7. Konsep Persentase Diskon

Gambar tersebut menunjukkan kesesuaian e-comic matematika dengan karakteristik PMR yaitu "terdapat keterkaitan antar materi [K5k2]" dan juga "penggunaan model [K5k3]".

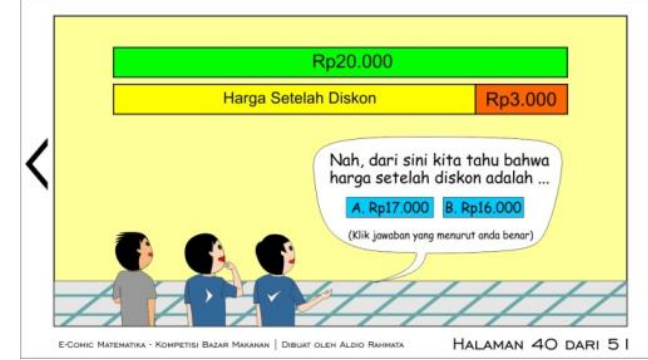

Gambar 8. Halaman Interaktif yang

Ditambahkan

Sedangkan pada gambar di atas, e-comic matematika telah memenuhi karakteristik PMR yaitu "terdapat kontribusi siswa [K5k4]" dalam menyelesaikan masalah serta "terdapat interaksi [K5k5]" antara siswa dengan e-comic matematika. Karena apabila siswa memilih jawaban, akan muncul panel baru yang menunjukkan benar atau belum benarnya jawaban yang dipilih oleh siswa, diikuti dengan pembahasan.

Berdasarkan penjelasan-penjelasan tersebut, dapat disimpulkan bahwa e-comic matematika berbasis PMR bermuatan etnomatematika materi telah memenuhi prinsip dan karakteristik PMR. Sehingga pada akhirnya semua karakteristik $e$ comic matematika yang ditentukan peneliti pada tahap analisis kebutuhan telah dipenuhi.

\section{Tahap Implement}

Tahap implementasi merupakan tahap pengujian $e$ comic matematika yang telah melalui tahap validasi dan revisi untuk diketahui kriteria kepraktisan dan keefektifannya. Pengujian e-comic matematika dilaksanakan pada tanggal 26 Januari 2021 melalui sistem daring dikarenakan pelaksanaan belajar mengajar di SMP Negeri 1 Krembung, Sidoarjo dilaksanakan secara daring akibat pandemi covid-19. Peneliti membuat grup Whatsapp bersama 12 siswa yang sesuai dengan karakteristik subjek dari peneliti dan salah satu guru matematika SMP Negeri 1
Krembung. Setelah itu, alur pengujian e-comic matematika adalah: (1) Peneliti memberikan $e$-comic berekstensi .apk pada grup whatsapp; (2) Siswa mendownload e-comic.apk dan meng-instal di smartphone masing-masing; (3) Siswa membaca e-comic matematika yang telah di-instal; (4) Siswa melapor kepada peneliti apabila telah selesai membaca $e$-comic matematika melalui chat pribadi; (5) Peneliti memberikan soal uji keefektifan kepada siswa yang telah selesai membaca $e$-comic matematika; (6) Siswa mengumpulkan hasil mengerjakan soal kepada peneliti melalui chat pribadi; dan (7) Peneliti memberikan angket penilaian kepraktisan $e$-comic matematika.

Dengan mengikuti petunjuk yang ada pada $e$-comic matematika, siswa melakukan belajar mandiri mengenai sub materi aritmetika sosial. Siswa membaca cerita yang telah diurutkan oleh peneliti sesuai dengan tahapan konsep materi yang disisipkan di dalam alur cerita. Siswa juga harus menjawab beberapa soal, karena sistem e-comic telah di-setting untuk tidak dapat dilanjutkan apabila siswa belum menjawab soal di halaman tersebut. E-comic yang dilandaskan pada prinsip dan karakteristik PMR berperan penting dalam memahamkan materi aritmetika sosial kepada siswa dengan tahapan konstruksi konsep secara mendalam.

Pada pelaksanaan pengujian kelayakan e-comic matematika, diperoleh hasil sebagai berikut.

\section{a) Kepraktisan}

Kepraktisan $e$-comic matematika berbasis PMR bermuatan etnomatematika materi aritmetika sosial ditentukan berdasarkan hasil pengisian angket penilaian kepraktisan oleh siswa. Persentase kepraktisan e-comic matematika berbasis PMR bermuatan etnomatematika materi aritmetika sosial yang diperoleh adalah 84,18\%. Berdasarkan kriteria kepraktisan yang diadaptasi dari Akbar (2017), maka dapat disimpulkan bahwa e-comic matematika berbasis PMR bermuatan etnomatematika aritmetika sosial memenuhi kriteria "praktis, atau dapat digunakan dengan sedikit revisi". Seperti pada penelitian Rohati, dkk. (2018) yang menyatakan bahwa komik matematika memperoleh kategori sangat praktis berdasarkan penilaian dari siswa yang telah mengisi angket kepraktisan. Pada penelitian tersebut siswa menyatakan bahwa komik matematika sangat menarik, menambah minat belajar, mudah dimengerti, dan sangat baik digunakan.

Keefektifan suatu media perlu diuji menggunakan instrumen. Peneliti menggunakan instrumen soal yang dikerjakan siswa secara mandiri untuk mendapatkan data efektifitas yang akurat. KKM yang ditentukan sekolah untuk siswa 
kelas VII adalah 75. Berdasarkan hasil pekerjaan siswa diperoleh $e$-comic matematika berbasis PMR bermuatan etnomatematika materi aritmetika sosial memperoleh persentase $83,33 \%$. Seperti halnya pada penelitian Lestari (2020) yang menguji keefektifan e-comic matematika dengan memberikan tes mandiri yang diberikan setelah siswa membaca e-comic matematika. Pada penelitian tersebut $e$-comic matematika dinyatakan efektif dikarenakan hasil dari tes mandiri siswa, 80\% siswa mencapai KKM. Berdasarkan kriteria uji keefektifan yang diadaptasi dari Akbar (2017:42) diperoleh kesimpulan bahwa e-comic matematika berbasis PMR bermuatan etnomatematika materi aritmetika sosial memenuhi kriteria "sangat efektif, atau dapat digunakan tanpa revisi”.

\section{Tahap Evaluate}

Peneliti melakukan evaluasi pada hasil validasi, kepraktisan, dan keefektifan e-comic matematika berbasis PMR bermuatan etnomatematika materi aritmetika sosial. Berikut adalah peninjauan terhadap analisis data hasil uji kevalidan, kepraktisan, dan keefektifan.

a) E-comic matematika telah memperoleh kriteria valid dengan sedikit revisi dikarenakan hasil persentase kevalidan yang diperoleh dari dua validator ahli adalah $82,95 \%$.

b) E-comic matematika memenuhi kriteria praktis dengan hasil $84,18 \%$ berdasarkan hasil penilaian angket kepraktisan oleh siswa sebagai subjek penelitian.

c) E-comic matematika telah memenuhi kriteria sangat efektif karena dari hasil tes dalam mengerjakan soal uji keefektifan, 83,33\% dari total subjek telah memenuhi KKM.

\section{Pembahasan}

Berdasarkan hasil dan analisis data pada tahap sebelumnya, peneliti memberikan pembahasan terhadap $e$ comic matematika yang telah dibuat serta kaitannya dengan beberapa hal antara lain:

1. Pemanfaatan Teknologi

Berdasarkan hasil analisis data pada uji kepraktisan diperoleh hasil bahwa siswa tidak mengalami kesulitan dalam menggunakan $e$-comic matematika. Hal tersebut nampak pada kemudahan instalasi $e$-comic matematika pada smartphone sampai dengan petunjuk penggunaannya yang juga dianggap siswa mudah untuk dipahami. E-comic matematika telah berekstensi .apk yang merupakan hasil publishing dari Adobe Flash Professional. Ekstensi .apk merupakan format khusus untuk smartphone android yang dapat langsung di-instal sehingga lebih hemat biaya, tahan lama, dan tidak memerlukan bahan konvensional untuk pendistribusiannya. Hal terebut sesuai dengan salah satu prinsip komik yaitu material light, strength, and ecosystem friendly dimana bahan yang digunakan harus kuat, ringan, dan ramah lingkungan (Gumelar, 2011).

Selain digunakan dalam pembelajaran, keberadaan e-comic matematika juga menumbuhkan literasi digital siswa dalam memanfaatkan smartphone mereka untuk aktivitas yang positif, terutama dalam suasana sekolah daring akibat pandemi covid-19. Siswa dapat memanfaatkan teknologi sebaik mungkin untuk membantu dalam memenuhi kebutuhan belajar meraka. Untuk itu, e-comic matematika berbasis PMR bermuatan etnomatematika merupakan salah satu alternatif yang dapat digunakan untuk belajar materi aritmetika sosial. Sejalan dengan pendapat dari Hermawan, dkk. (2018) yang menyatakan bahwa guru diharapkan mampu memanfaatkan teknologi agar siswa dapat meningkatkan kemampuannya (literasi digital) dan memotivasi siswa selama pembelajaran.

2. Memenuhi Kebutuhan dalam Pembelajaran

Berdasarkan hasil wawancara peneliti dengan salah satu siswa, pembelajaran daring di sekolah dilaksanakan dengan menggunakan buku paket elektronik yang dimiliki siswa. Namun siswa merasa belum cukup mendapatkan pemahaman karena guru tidak menjelaskan dengan detail akibat keterbatasan waktu dan ruang yang dialami siswa maupun guru. Siswa merasa membutuhkan penjelasan lebih lanjut mengenai materi yang diajarkan. Sehingga bagi mereka, e-comic matematika dapat menjadi penyegaran sekaligus membantu siswa dalam memahami materi aritmetika sosial dengan lebih baik, sesuai dengan pengisian angket uji kepraktisan yang menyatakan bahwa pembelajaran menggunakan $e$ comic matematika lebih baik dibandingkan tanpa $e$ comic matematika (buku). Hal tersebut sejalan dengan penelitian Hermawan, dkk. (2018) yang memperoleh informasi bahwa siswa merasa senang dan tidak bosan dengan media pembelajaran $e$-comic dan mereka dapat memahami materi yang disampaikan.

3. Karakteristik E-comic Matematika Berbasis PMR Bermuatan Etnomatematika

Pada subbab sebelumnya telah dibahas mengenai langkah-langkah pengembangan e-comic matematika berbasis PMR bermuatan etnomatematika yang menghasilkan kriteria kevalidan dengan tingkat kevalidan 82,95\%, tingkat kepraktisan sebesar $84,18 \%$, dan keefektifan dengan $83,33 \%$ siswa mencapai KKM setelah uji coba tes mandiri. Dalam proses tersebut e-comic matematika yang 
dikembangkan telah disesuaikan dengan karakteristik yang ditentukan peneliti berdasarkan pendapat para ahli. Setiap bagian dalam e-comic matematika disusun berdasarkan karakteristik yang ada sehingga dalam pembuatannya memiliki batasan atau tolok ukur. Karakteristik yang menjadi pedoman peneliti dalam membuat e-comic matematika adalah $(K 1)$ menarik bagi siswa, dibuktikan dengan hasil penilaian validator ahli dan diperkuat hasil uji kepraktisan dari subjek penelitian; (K2) sesuai dengan karakteristik siswa, yang telah ditunjukkan pada pemilihan ide cerita tentang kehidupan siswa SMP yang sedang mengikuti kegiatan di sekolahnya; (K3) dikembangkan menggunakan teknologi komputer, ditunjukkan pada bagian develop yaitu peneliti menggunakan aplikasi Corel Draw untuk membuat desain secarra keseluruhan dan dilanjutkan dengan Adobe Flash Professional sebagai finishing tahapan pembuatan $e$ comic sehingga dapat menjadi berbentuk apk; $(K 4)$ memuat konteks etnomatematika, ditunjukkan pada bagian develop dimana peneliti menyesuaikan antara materi yang akan disampaikan dengan konteks yang dapat dipahami dan memberikan wawasan untuk siswa, sehingga peneliti menyisipkan etnomatematika penggunaan satuan lokal pada jual beli masyarakat Sidoarjo yang akan sinkron dengan materi aritmetika sosial; dan (K5) memuat prinsip dan karakteristik PMR, telah muncul pada bagian develop dimana peneliti dengan saran dan evaluasi dari vaidator ahli memastikan terpenuhinya prinsip dan karakteristik PMR. Prinsip K5pl muncul pada bagian cerita ketika tokoh menggunakan aritmetika sosial untuk strategi jual beli, prinsip K5p2 muncul pada bagian cerita ketika tokoh mengkaji kembali konsep aritmetika sosial saat tokoh lain ingin dijelaskan, prinsip K5p3 muncul pada bagian cerita dimana peneliti memberikan diagram untuk mengonstruksi konsep aritmetika sosial. Selain itu karakteristik PMR $K 5 k 1$, $K 5 k 2, K 5 k 3, K 5 k 4$, dan $K 5 k 5$ juga telah termuat di dalam isi e-comic sehingga e-comic telah memenuhi prinsip dan karakteristik PMR.

4. Keterbatasan Penelitian

E-comic matematika berbasis PMR bermuatan etnomatematika telah dikembangkan berdasarkan langkah-langkah ADDIE yang terdiri dari (1) Analyze, (2) Design, (3) Develop, (4) Implement, dan (5) Evaluate. Namun pada tahap implement, peneliti menjalankannya melalui sistem daring atau online dikarenakan keterbatasan waktu dan ruang akibat pandemi covid-19. Peneliti mendistribusikan $e$ comic.apk, memberikan angket uji kepraktisan, dan memberikan soal uji keefektifan kepada subjek melalui whatsapp group.

\section{PENUTUP}

\section{Simpulan}

Berdasarkan hasil, analisis data, dan pembahasan, maka dapat diambil simpulan bahwa :

1. Pengembangan e-comic matematika berbasis PMR bermuatan etnomatematika materi aritmetika sosial telah mengikuti tahapan pengembangan model ADDIE, diuraikan sebagai berikut.

a. Tahap Analisis

Pada tahap analisis, peneliti telah melakukan analisis kondisi sekolah serta kurikulum untuk menentukan konsep media yang sesuai untuk memenuhi kebutuhan sekolah. Kemudian peneliti menentukan karakteristik e-comic matematika berbasis PMR bermuatan etnomatematika materi aritmetika sosial yang diperoleh dari kajian teori dari berbagai ahli untuk dijadikan pedoman pada pembuatan media $e$-comic matematika pada tahap selanjutnya.

b. Tahap Desain Pada tahap ini peneliti telah membuat kerangka dasar e-comic matematika, menjabarkan komponen-komponen yang harus ada dalam $e$ comic matematika berdasarkan karakteristik yang telah dibuat pada tahap sebelumnya. Selain itu peneliti juga membuat instrumen uji kevalidan, kepraktisan, dan keefektifan.

c. Tahap Pengembangan

Pada tahap pengembangan, e-comic matematika mulai dibuat lebih spesifik berdasarkan kerangka dasar dan juga karakteristik e-comic matematika yang telah ditentukan dari tahap sebelumnya. Selain itu peneliti juga melakukan validasi $e$-comic matematika untuk menguji tingkat kevalidan.

d. Tahap Implementasi

E-comic matematika hasil dari tahap pengembangan dapat digunakan untuk uji kelayakan di lapangan. Uji kelayakan terdiri dari uji kepraktisan dan keefektifan e-comic matematika.

e. Tahap Evaluasi

E-comic matematika yang telah diuji kevalidan, kepraktisan, serta keefektifannya dievaluasi kembali. Pada tahap ini peneliti dapat mengetahui kriteria valid, praktis, dan efektif e-comic matematika yang telah dikembangkan.

2. Berdasarkan hasil uji kelayakan e-comic matematika, diketahui kriteria kevalidan, kepraktisan, dan keefektifan e-comic matematika sebagai berikut.

a. Valid, karena e-comic matematika yang dikembangkan telah mendapatkan penilaian dari dua validator ahli media dan ahli materi dengan 
persentase kevalidan $82,95 \%$. Sehingga e-comic matematika berbasis PMR bermuatan etnomatematika aritmetika sosial dinyatakan valid dan dapat digunakan dengan sedikit revisi.

b. Praktis, didasarkan pada hasil penilaian angket uji kepraktisan yang dilakukan oleh subjek penelitian setelah diberikan e-comic matematika yang memperoleh persentase kepraktisan $84,18 \%$. Sehingga e-comic matematika berbasis PMR bermuatan etnomatematika materi aritmetika sosial dinyatakan praktis.

c. Sangat efektif, karena dari hasil tes mandiri yang dikerjakan oleh subjek penelitian setelah diberi $e$ comic matematika, 83,33\% dari total subjek telah mencapai KKM sekolah yaitu 75. Sehingga $e$ comic matematika berbasis PMR bermuatan etnomatematika materi aritmetika sosial dinyatakan sangat efektif.

Secara keseluruhan e-comic matematika berbasis PMR bermuatan etnomatematika materi aritmetika sosial berkualitas baik dan dapat digunakan dalam pembelajaran materi aritmetika sosial karena telah memenuhi kriteria valid, praktis, dan sangat efektif.

\section{Saran}

Serangkaian proses penelitian pengembangan telah dilakukan peneliti sampai diperoleh simpulan. Namun dalam proses penelitian ditemukan adanya beberapa kekurangan dari hasil penelitian ini. Sehingga peneliti memberikan saran sebagai berikut.

1. Penambahan sub materi aritmetika sosial yang lain yaitu bunga, netto, dan tara. Sehingga e-comic mencakup semua materi aritmetika sosial.

2. Melakukan eksplorasi konteks etnomatematika yang sekaligus dapat digunakan untuk mengonstruksi konsep suatu materi yang dibahas. Sehingga etnomatematika tidak hanya berperan menjadi tema cerita e-comic.

3. Mengembangkan ide, meningkatkan kemampuan mendesain, serta teknik animasi singkat untuk memberikan daya tarik lebih tinggi pada e-comic yang dikembangkan.

4. Meningkatkan kontrol dalam sistem uji kelayakan sehingga menjamin keakuratan data.

\section{DAFTAR PUSTAKA}

Akbar, S. (2017). Instrumen Perangkat Pembelajaran (Cetakan ke-5). Bandung: PT. Remaja Rosdakarya.
Cahdriyana, R. A., \& Richardo, R. (2016). Karakteristik Media Pembelajaran Berbasis Komputer untuk Siswa SMP. AlphaMath, 1-11.

Freudenthal, H. (1991). Revisiting Mathematics Education : China Lectures. Dordrecht: Kluwer Academic Publishers.

Gumelar, M. S. (2011). Comic Making - Cara Membuat Komik. Jakarta Barat: Indeks.

Hardiarti, S. (2017). Etnomatematika: Aplikasi Bangun Datar Segiempat pada Candi Muaro Jambi. Aksioma, 99-110.

Hermawan, L. I., Hobri, Murtikusuma, R. P., Setiawan, S., \& Yudianto, E. (2018). Pengembangan E-comic Berbantuan Pixton pada Materi Program Linear Dua Variabel. Kadikma, 78-88.

Irawan, A., \& Kencanawaty, G. (2017). Imlementasi Pembelajaran Matematika Realistik Berbasis Etnomatematika. Medives : Journal of Mathematics Education IKIP Veteran Semarang, 74-81.

Kemdikbud. (2019). Laporan Hasil Ujian Nasional. Retrieved from Pusat Penilaian Pendidikan: Kementerian Pendidikan dan Kebudayaan: https://hasilun.puspendik.kemdikbud.go.id

Lestari, A. C. (2019). Development of Education Comics Based Realistic Mathematics Education on Fraction Material. JRPIPM, 15-23.

Lestari, A. C. (2020). Pengembangan E-comic Matematika Berbasis Pendekatan Matematika Realistik pada Materi Perbandingan Senilai. (Skripsi tidak diterbitkan).

Mashuri, S. (2019). Media Pembelajaran Matematika. Yogyakarta: CV Budi Utama.

Nida, I. K., Buchori, A., \& Murtianto, Y. H. (2017). Pengembangan Comic Math dengan Pendekatan Etnomatematika pada Materi Kubus dan Balok di SMP. Aksioma, 31-40.

Nur, M. A. (2018). BIPA sebagai Strategi Kebudayaan dan Implementasi dalam MetodePembelajaran. Prosiding Semnas KBSP $V$, Universitas Muhammadiyah Malang, (pp. 86-91). Malang.

Rachmawati, I. (2011). Eksplorasi Etnomatematika Masyarakat Sidoarjo. Ejournal Unnes.

Rohati, Winarni, S., \& Hidayat, R. (2018). Pengembangan Media Pembelajaran Komik Matematika Berbasis Problem Based Learning 
dengan Manga Studio V05 dan Geogebra. Edumatica, 81-91.

Siregar, H. F., Siregar, Y. H., \& Melani. (2018). Perancangan Aplikasi Komik Hadist Berbasis Multimedia. Jurnal Teknologi Informasi, 113121.

Siregar, N., Suherman, Masykur, R., \& Ningtias, R. S. (2019). Pengembangan Media Pembelajaran Ecomic dalam Pembelajaran Matematika. Journal of Mathematics Education and Science (JaMES), 11-19.
Siswono, T. Y. (2019). Paradigma Penelitian Pendidikan (Pengembangan Teori dan Aplikasi Pendidikan Matematika). Surabaya: PT. Remaja Rosdakarya.

Tohir, M. (2019). Hasil PISA Indonesia Tahun 2018 Turun Dibanding Tahun 2015. Situbondo: Universitas Ibrahimy. Retrieved 2020 13, November.

Zainiyati, H. S. (2017). Pengembangan Media Pembelajaran Berbasis ICT : Agama Islam. Jakarta: PT. Kharisma Putra Utama. 